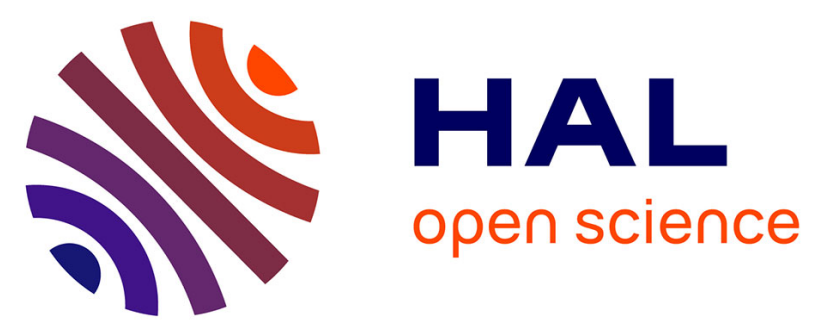

\title{
Characterization of species-related differences in the pharmacology of tachykinin NK receptors 1,2 and 3
}

Agnes Leffler, Ingela Ahlstedt, Susanna Engberg, Arne Svensson, Martin

Billger, Lisa Öberg, Magnus Bjursell, Erik Lindström, Bengt von Mentzer

\section{To cite this version:}

Agnes Leffler, Ingela Ahlstedt, Susanna Engberg, Arne Svensson, Martin Billger, et al.. Characterization of species-related differences in the pharmacology of tachykinin NK receptors 1,2 and 3. Biochemical Pharmacology, 2009, 77 (9), pp.1522. 10.1016/j.bcp.2009.01.020 . hal-00493489

\section{HAL Id: hal-00493489 \\ https://hal.science/hal-00493489}

Submitted on 19 Jun 2010

HAL is a multi-disciplinary open access archive for the deposit and dissemination of scientific research documents, whether they are published or not. The documents may come from teaching and research institutions in France or abroad, or from public or private research centers.
L'archive ouverte pluridisciplinaire HAL, est destinée au dépôt et à la diffusion de documents scientifiques de niveau recherche, publiés ou non, émanant des établissements d'enseignement et de recherche français ou étrangers, des laboratoires publics ou privés. 


\section{Accepted Manuscript}

Title: Characterization of species-related differences in the pharmacology of tachykinin NK receptors 1, 2 and 3

Authors: Agnes Leffler, Ingela Ahlstedt, Susanna Engberg, Arne Svensson, Martin Billger, Lisa Öberg, Magnus Bjursell, Erik Lindström, Bengt von Mentzer

PII: S0006-2952(09)00055-0

DOI: doi:10.1016/j.bcp.2009.01.020

Reference: BCP 10080

To appear in: $\quad B C P$

Received date: $\quad$ 19-11-2008

Revised date: 27-1-2009

Accepted date: $\quad 30-1-2009$

Please cite this article as: Leffler A, Ahlstedt I, Engberg S, Svensson A, Billger M, Öberg L, Bjursell M, Lindström E, von Mentzer B, Characterization of species-related differences in the pharmacology of tachykinin NK receptors 1, 2 and 3, Biochemical Pharmacology (2008), doi:10.1016/j.bcp.2009.01.020

This is a PDF file of an unedited manuscript that has been accepted for publication. As a service to our customers we are providing this early version of the manuscript. The manuscript will undergo copyediting, typesetting, and review of the resulting proof before it is published in its final form. Please note that during the production process errors may be discovered which could affect the content, and all legal disclaimers that apply to the journal pertain. 
Short title: NK receptor pharmacology

\section{Characterization of species-related differences in the pharmacology of tachykinin NK receptors 1, 2 and 3.}

Agnes Leffler ${ }^{a}$, Ingela Ahlstedt $^{a}$, Susanna Engberg ${ }^{a}$, Arne Svensson $^{a}$, Martin Billger $^{b}$, Lisa Öberg ${ }^{a}$, Magnus Bjursell ${ }^{1}$, Erik Lindström ${ }^{2}$ and Bengt von Mentzer ${ }^{*}$ AstraZeneca R\&D, Mölndal, Sweden.

*Corresponding author: Dr. Bengt von Mentzer, Pharmnovo AB, Medicinaregatan 8A, S-413 46 Göteborg, Sweden. Tel.: +46 31 7411816, Fax. +46 31 7411701, Email: bengt.mentzer@pharmnovo.com

${ }^{1}$ Current affiliation: Royal Institute of technology, Albanova University Centre, SE10691 Stockholm, Sweden

${ }^{2}$ Current affiliation: Medivir AB, PO Box 1086, S-141 22, Huddinge, Sweden

${ }^{\mathrm{a}}$ Department of Bioscience

${ }^{\mathrm{b}}$ Safety Assessment

Key words: Aprepitant; Saredutant; Talnetant; NK receptors; Species difference; NKreceptor function; Chemistry; NK-receptor sequences

Abbreviations: NKR, tachykinin NK receptor; SP, Substance P; NKA, Neurokinin A; NKB, Neurokinin B; AA, amino acids; FLIPR, Fluorometric Imaging Plate Reader; TM. trans membrane 


\begin{abstract}
Tachykinin NK receptors (NKR) differ to a large degree among species with respect to their affinities for small molecule antagonists. The aims of the present study were to clone NKRs from gerbil $\left(\mathrm{NK}_{2} \mathrm{R}\right.$ and $\left.\mathrm{NK}_{3} \mathrm{R}\right)$ and $\operatorname{dog}\left(\mathrm{NK}_{1} \mathrm{R}, \mathrm{NK}_{2} \mathrm{R}, \mathrm{NK}_{3} \mathrm{R}\right)$ in which the sequence was previously unknown and to investigate the potency of several NKR antagonists at all known human, dog, gerbil and rat NKRs.

The NKR protein coding sequences were cloned and expressed in CHO cells. The inhibitory concentrations of selective and non-selective NKR antagonists were determined by inhibition of agonist-induced mobilization of intracellular $\mathrm{Ca}^{2+}$. Receptor homology models were constructed based on the rhodopsin crystal structure to investigate and identify the antagonist binding sites and interaction points in the trans membrane $(\mathrm{TM})$ regions of the NKRs.

Data collected using the cloned $\operatorname{dog} \mathrm{NK}_{1} \mathrm{R}$ confirmed that the $\operatorname{dog} \mathrm{NK}_{1} \mathrm{R}$ displays similar pharmacology as the human and the gerbil $\mathrm{NK}_{1} \mathrm{R}$, but differs greatly from the mouse and the rat $\mathrm{NK}_{1} \mathrm{R}$. Despite species-related AA differences located close to the antagonist binding pocket of the $\mathrm{NK}_{2} \mathrm{R}$, they did not affect the potency of the antagonists ZD6021 and saredutant. Two AA differences located close to the antagonist binding site of $\mathrm{NK}_{3} \mathrm{R}$ likely influence the $\mathrm{NK}_{3} \mathrm{R}$ antagonist potency, explaining the 3-10-fold decrease in potency observed for the rat $\mathrm{NK}_{3} \mathrm{R}$. For the first time, detailed pharmacological experiments in vitro with cloned NKRs demonstrate that not only human, but also dog and gerbil NKR displays similar antagonist pharmacology while rat diverges significantly with respect to $\mathrm{NK}_{1} \mathrm{R}$ and $\mathrm{NK}_{3} \mathrm{R}$.
\end{abstract}




\section{Introduction}

Several small molecule antagonists selective for tachykinin $N_{1} R, N_{2} R$ and $N_{3} R$ are in clinical development and the selective $\mathrm{NK}_{1} \mathrm{R}$ antagonist aprepitant is approved for treatment of emesis in response to cytostatic treatment in cancer patients [1]. During the development of selective $\mathrm{NK}_{1} \mathrm{R}$ antagonists, Beresford et al. discovered large discrepancies in the affinity for $\mathrm{NK}_{1} \mathrm{R}$ from different species [2]. This led to the $\mathrm{NK}_{1} \mathrm{R}$ family being grouped into two sub-families based on the orthologous receptor's affinity to small molecule antagonists. The first sub-family consists of the human, guinea pig, rabbit, dog, gerbil and ferret $\mathrm{NK}_{1} \mathrm{R}$, and the second sub-family of the rat and mouse homologues $[\mathbf{2 , 3 , 4 , 5 ]}$ Thus, several disease-related animal models in species other than rat or mouse have been developed for evaluation of $\mathrm{NK}_{1} \mathrm{R}$ antagonists $[6,7,8,9,10]$ Amino acid residues in the $\mathrm{NK}_{1} \mathrm{R}$ responsible for speciesdependent differences in antagonist pharmacology have been studied in detail, especially human Glu97, Val116 and Ser290 [5,11,12,13,14]However, although the dog appears to be an appropriate species in detecting anti-emetic effects with selective $\mathrm{NK}_{1} \mathrm{R}$ antagonists intended for clinical use [15], the pharmacology of the $\operatorname{dog} \mathrm{NK}_{1} \mathrm{R}$ at the molecular level, and its homology to the human $\mathrm{NK}_{1} \mathrm{R}$, remain unknown to our knowledge.

Consistent species-related differences in the pharmacology of $\mathrm{NK}_{2} \mathrm{R}$ have not been reported either, although recent publications demonstrated that the selective $\mathrm{NK}_{2} \mathrm{R}$ antagonist MEN15596 and analogues MEN14268 and MEN13918 had a marked species selectivity for inhibiting $\mathrm{NK}_{2} \mathrm{R}$-mediated effects in human, guinea pig and pig urinary bladder, while being 1,000-fold less potent at the rat and mouse $\mathrm{NK}_{2} \mathrm{R}$ expressed in urinary bladder $[\mathbf{1 6 , 1 7}]$. By contrast, species-dependent differences were 
not observed with MEN11420 (nepadutant) [18] or saredutant [19] Detailed sitedirected mutagenesis studies suggested that the Ile202 residue, located in the upper part of TM5 in the human $\mathrm{NK}_{2} \mathrm{R}$ was, at least in part, responsible for these differences [16] Still, the homology between the human $\mathrm{NK}_{2} \mathrm{R}$ and that of species commonly used in tachykinin receptor pharmacology studies, such as dog and gerbil, has not been reported.

Furthermore, species-related differences in functional response profiles between human and mouse/rat have been reported for selective tachykinin $\mathrm{NK}_{3} \mathrm{R}$ antagonists. Compounds from different structural classes have 5-10-fold lower potency and 10-50fold lower affinity for rodent $\mathrm{NK}_{3} \mathrm{R}$ compared to human counterparts [20,21] Sitedirected mutagenesis studies indicate that two amino acids in the second trans membrane domain of the human $\mathrm{NK}_{3} \mathrm{R}$ (Met134 and Ala146) were responsible for these species differences $[\mathbf{2 0 , 2 2}]$ However, as is the case for $\mathrm{NK}_{2} \mathrm{R}$, the identity of $\mathrm{NK}_{3} \mathrm{R}$ from dog and gerbil remain unknown.

Thus, there are clearly gaps in our knowledge with respect to which species most likely will predict clinical efficacy and selectivity for $\mathrm{NK}_{1} \mathrm{R}, \mathrm{NK}_{2} \mathrm{R}$ or $\mathrm{NK}_{3} \mathrm{R}$ antagonists. Furthermore, the lack of antagonist affinity data will complicate species selection for toxicological studies intended to detect adverse effects upon blocking of receptor signalling. In the current study, we have cloned and sequenced the dog $N_{1} R, N_{2} R$ and $N_{3} R$ and the gerbil $N_{2} R$. This should increase the understanding of the molecular mechanisms underlying the species related differences in NKR pharmacology, which would facilitate more relevant model system selection. 


\section{Material and Methods}

\subsection{Chemicals}

Substance P, neurokinin A and Pro7neurokinin B were purchased from Bachem

(Peninsula Laboratories Inc, San Carlos, CA). ZD6021 was synthesized at

AstraZeneca, Wilmington, USA [23]. Aprepitant [24], RP67580 [25], CP-99,994 [26], saredutant [19], talnetant $[\mathbf{2 7 , 2 8}]$ and osanetant $[\mathbf{2 9 , 3 0 ]}$ were synthesized at AstraZeneca Mölndal, Sweden.

\subsection{Molecular cloning of the gerbil and dog NK receptors}

The sequences for the human and rat NKR subtypes and the gerbil $\mathrm{NK}_{1} \mathrm{R}$ have been published previously (see Table 1 for accession numbers, [5]. The receptor sequences for the gerbil $\mathrm{NK}_{2} \mathrm{R}$ and the $\operatorname{dog} \mathrm{NK}_{1} \mathrm{R}, \mathrm{NK}_{2} \mathrm{R}$ and $\mathrm{NK}_{3} \mathrm{R}$ were largely unknown and are presented in this paper and submitted to the EMBL GenBank database under the accession numbers listed in Table 2 . The gerbil $\mathrm{NK}_{3} \mathrm{R}$ sequence has been cloned and was presented in a recent study [31].

Dog hypothalamus was used as a source for cloning $\mathrm{NK}_{1} \mathrm{R}$ and $\mathrm{NK}_{3} \mathrm{R}$. Dog ileum and gerbil colon were used as sources for cloning of the respective $\mathrm{NK}_{2} \mathrm{R}$. Total RNA was prepared from the different tissues with RNA-STAT-60 (Tel-Test Inc, Friendswood, Texas, USA). One $\mu \mathrm{g}$ of total RNA from each tissue sample was used for the first strand cDNA synthesis using SMART RACE cDNA Amplification kit (BD Biosciences, Mountain View, CA, USA). ClustalW alignment of $\mathrm{NK}_{1} \mathrm{R}, \mathrm{NK}_{2} \mathrm{R}$ and $\mathrm{NK}_{3} \mathrm{R}$ sequences from human, rat, mouse and guinea pig was used to select primers with high homology between different species. Primers used in the $3^{\prime} \mathrm{RACE}$ and in 
the 5'RACE are listed in Table 2. The RACE fragments were characterized and cloned fragments containing gerbil and dog specific $\mathrm{NK}_{1} \mathrm{R}, \mathrm{NK}_{2} \mathrm{R}$ and $\mathrm{NK}_{3} \mathrm{R}$ sequences spanning the open reading frame were identified.

Complementary DNA $(2.5 \mu \mathrm{l})$ from the harvested tissues indicated above was used in the optimized full-length PCR with forward and reverse primers (20 $\mu \mathrm{M}$ of each), 1xPCR buffer, $5 \mathrm{mM}$ of each dNTP and 1 U Pfu Ultra (Stratagene, La Jolla, CA, USA). A Kozak sequence (GCCACC) was introduced before the ATG in each construct. Conditions were optimized for each primer pair used. The resulting PCR products for the gerbil and $\operatorname{dog} \mathrm{NK}_{1} \mathrm{R}$ and $\mathrm{NK}_{2} \mathrm{R}$ were cloned into pIREShyg2 expression vector (Clontech, Palo Alto, CA, USA). The full-length cDNA of dog and gerbil $\mathrm{NK}_{3}$ receptor was cloned into pCDNA/FRT expression vector (Invitrogen, Carlsbad, CA, USA). In order to construct a full length clone of $\operatorname{dog} \mathrm{NK}_{3} \mathrm{R}$, the $5^{\prime}$-end of the $\operatorname{dog} \mathrm{NK}_{3} \mathrm{R}$ was cloned using genomic sequence data (TI number 356163905) from a trace file as a template for PCR reactions.

Multiple sequence alignments were constructed using ClustalX version 2.0 [32], and the TM domains were predicted using the TMHMM server version 2.0 (http://www.cbs.dtu.dk/services/TMHMM/). A position in the alignments is considered TM if the majority of the individual sequences are predicted to be TM at that position.

\subsection{Cell culture and transfection}

Chinese Hamster Ovary (CHO) cells (ATCC, Middlesex, UK) or CHO-FlpIN cells (Invitrogen, Carlsbad, CA, USA) were transfected with the different constructs. All accession numbers for the sequences used to transfect the $\mathrm{CHO}$ cells are listed in table 
2. $\mathrm{NK}_{1-3} \mathrm{R}$-containing clones were selected by growth in appropriate selection media and tested for functionality in a $\mathrm{Ca}^{2+}$ mobilization assay.

$\mathrm{CHO}$ cells stably expressing human $\mathrm{NK}_{1} \mathrm{R}$ was supplied by AstraZeneca $\mathrm{R} \& \mathrm{D}$,

Wilmington, $\mathrm{USA}$ and human $\mathrm{NK}_{2} \mathrm{R}$, rat $\mathrm{NK}_{1} \mathrm{R}$, rat $\mathrm{NK}_{2} \mathrm{R}$ and rat $\mathrm{NK}_{3} \mathrm{R}$ were transfected in house (see Table 1 for gene accession numbers). Stable transfectants were maintained by supplementing culture media (NutMix F12 (HAM) with Glutamax I and 10\% FBS) (Invitrogen, Carlsbad, CA, USA) with suitable selection depending on the expressing vector. Cultures were kept at $37^{\circ} \mathrm{C}$ in a $5 \% \mathrm{CO}_{2}-$ incubator and routinely passaged when $70-80 \%$ confluent for up to $20-25$ passages.

\subsection{Calcium mobilization assay}

$\mathrm{Ca}^{2+}$ mobilization was studied in $\mathrm{CHO}$ cells or in CHO FlpIn cells stably expressing human, rat, gerbil or dog NK1-3 receptors using the cytoplasmic $\mathrm{Ca}_{\mathrm{i}}{ }^{2+}$ indicator Fluo4 (TEFLABS 0152, Austin, TX, USA). Cells were seeded into black-walled clearbase 96-well plates (Costar, \#3904) at a density of 35,000 cells per well in culture media and grown for $24 \mathrm{~h}$ in a $37^{\circ} \mathrm{C} \mathrm{CO}_{2}$-incubator. The cells were incubated with 4 $\mu \mathrm{M}$ of Fluo-4 (TEFLABS 0152) in loading media (Nut Mix F12 (HAM), glutamax I, 22 mM HEPES, 2.5 mM probenicid (P-8761, Sigma, St. Louis, MO, USA) and 0.04 \% pluronic F-127 (P-2443 Sigma, St. Louis., MO, USA) for 30 minutes in a $37^{\circ} \mathrm{C}$ $\mathrm{CO}_{2}$-incubator. The Fluo-4-loaded cells were then washed three times in assay buffer (Hanks Balanced Salt Solution, $20 \mathrm{mM}$ HEPES, $2.5 \mathrm{mM}$ probenicid and 0.1\% BSA). The plates were placed into the Fluorometric Imaging Plate Reader (FLIPR ${ }^{\mathrm{TM}}$ ) to monitor cell fluorescence $(\lambda \mathrm{ex}=488 \mathrm{~nm}, \lambda \mathrm{em}=540 \mathrm{~nm})$ before and after the addition of antagonists and/or agonists. Antagonists and agonists were dissolved in assay buffer (final DMSO, D2650, Sigma. concentration kept below 1\%) in 96-well plates 
and added to the loaded cells by the automated pipettor in the FLIPR ${ }^{\mathrm{TM}}$. Loaded cells were pre-incubated with antagonists for 2 minutes before addition of agonist $(0.08 \mathrm{nM}$ SP for $\mathrm{NK}_{1} \mathrm{R}, 0.15 \mathrm{nM}$ NKA for $\mathrm{NK}_{2} \mathrm{R}$ and $1.0 \mathrm{nM}$ pro7NKB for $\mathrm{NK}_{3} \mathrm{R}$ ). $\mathrm{Ca}_{\mathrm{i}}{ }^{2+}$ responses were measured as peak fluorescence intensity minus basal fluorescence after agonist addition.

\subsection{Rhodopsin homology model}

The sequences of the human $\mathrm{NK}_{1-3} \mathrm{R}$ were aligned to the bovine rhodopsin and a subset of rhodopsin sequences, covering different degrees of sequence identity. The pair wise alignments of $\mathrm{NK}_{1-3} \mathrm{R}$ and rhodopsin, were extracted and adjusted manually to optimize compatibility with structure and frequently occurring sequence motifs amongst GPCRs. The rhodopsin- $\mathrm{NK}_{1-3} \mathrm{R}$ alignment was used as input for the automatic modeling and used for the evaluation of the WhatCheck module [33]. All binding site results and discussions are based on predictions drawn from NKR modified rohdopsin homology model. A limitation of the Whatif modeling tool is that insertions and gaps are not considered. In this case, however, the active site should not be affected by this limitation.

\subsection{Data analysis}

The calcium mobilization data generated in vitro were fitted to a four parameter equation using Excel Fit. $\mathrm{IC}_{50} \mathrm{~s}$ for antagonists were determined from concentrationresponse curves for each compound. Potency $\left(\mathrm{K}_{\mathrm{B}}\right)$-values for antagonists were calculated using the Cheng-Prusoff equation [34] and expressed as $\mathrm{pK}_{\mathrm{B}}$-values $\left(\mathrm{pK}_{\mathrm{B}}=\right.$ $\left.-\log \mathrm{K}_{\mathrm{B}}\right)$. All data are expressed as Mean \pm S.E.M. 


\section{Results}

\subsection{Sequence characterization and antagonist pharmacology of the tachykinin $\mathrm{NK}_{1}$} receptor

Multiple sequence alignments of the gerbil, human, dog, rat, mouse and guinea pig $\mathrm{NK}_{1} \mathrm{R}$ are shown in Fig. 1A. Unlike rat and gerbil, the dog $\mathrm{NK}_{1} \mathrm{R}$ displays $100 \%$ homology with human in the trans-membrane regions. Thus, the Val116 and Ile290 residues, previously identified as important for antagonist binding, are identical between the dog and the human $\mathrm{NK}_{1}$ receptor sequences. Also extracellular residues such as Glu97 have also been suggested as being responsible for species selectivity of antagonists. Indeed, gerbil and $\operatorname{dog} \mathrm{NK}_{1} \mathrm{R}$ also contained a Glu residue in this position while rat and mouse counterparts contained Val97.

The selective $\mathrm{NK}_{1} \mathrm{R}$ antagonists aprepitant (Fig. 1B, Table 3), CP99,994 (Table 3), and the pan-NK antagonist ZD6021 (Table 3) were slightly more potent (5-10 fold) inhibitors of the SP-induced responses in cells expressing the dog compared to the human $\mathrm{NK}_{1} \mathrm{R}$. RP67580 displayed similar potency at $\mathrm{NK}_{1} \mathrm{R}$ from all species evaluated (Table 3).

Fig $1 \mathrm{C}$ illustrates a rhodopsin- $\mathrm{NK}_{1} \mathrm{R}$ homology model which emphasizes the role of AA 116 and 290 in dictating species differences in $\mathrm{NK}_{1} \mathrm{R}$ antagonist pharmacology. The polar 290Ser in rat is smaller and less hydrophobic compared to the non-polar 290Ile present in human and dog $\mathrm{NK}_{1} \mathrm{R}$. In contrast, the Leu116Val (rat/human) is a rather conservative AA exchange. There are no other species-related differences in any of the other residues found to be close to the aprepitant binding site using this model (Fig 1C). 


\subsection{Sequence characterization and antagonist pharmacology at the tachykinin $\mathrm{NK}_{2}$} receptor

The alignments of the gerbil, human, dog, rat, mouse and guinea pig $\mathrm{NK}_{2} \mathrm{Rs}$, are shown in Fig. 2A. The residues located in the proposed saredutant binding site differ between species. Position 202 located within TM 5 is an Ile in the human and dog $\mathrm{NK}_{2} \mathrm{R}$ while the gerbil and rat $\mathrm{NK}_{2} \mathrm{R}$ have a Phe in this position. Position 205, also located in TM 5, is Ile in human, rat and $\operatorname{dog} \mathrm{NK}_{2} \mathrm{R}$ and Val in gerbil $\mathrm{NK}_{2} \mathrm{R}$, while position 267 (located in TM6) has Leu in the human, rat and gerbil $\mathrm{NK}_{2} \mathrm{R}$, which is replaced by a Phe in the $\operatorname{dog} \mathrm{NK}_{2} \mathrm{R}$.

Despite the interspecies differences in AA in TM regions, the selective $\mathrm{NK}_{2} \mathrm{R}$ antagonist saredutant (Fig. 2B, Table 3), and the pan-NKR antagonist ZD6021 (Table 3), had a similar potency at the $\mathrm{NK}_{2} \mathrm{R}$ from the various species.

Fig. $2 \mathrm{C}$ illustrates the chemical structures of AA that differ between species and that are presumed to be involved in $\mathrm{NK}_{2} \mathrm{R}$ binding of saredutant. All the differences between $\mathrm{AA}$ in the $\mathrm{NK}_{2} \mathrm{R}$ binding site contain neutral, nonpolar AA. Even though there are differences in the hydrophobicity among residues, they do not seem to affect the potency of the tested $\mathrm{NK}_{2} \mathrm{R}$ antagonists (Table 3).

\subsection{Sequence characterization and antagonist pharmacology at the tachykinin $\mathrm{NK}_{3}$} receptor

Alignments of the gerbil, human, dog, rat, mouse and guinea pig $\mathrm{NK}_{3} \mathrm{R}$ sequences are shown in Fig. 3A. Key residues important for the binding of talnetant (Met134, Ala146 and Ile317) are identical between gerbil, dog and human, while the corresponding residues in the rat and mouse sequences are Val134, Gly146 and Val317 respectively. 
The selective $\mathrm{NK}_{3} \mathrm{R}$ antagonists talnetant (Fig. 3B and Table 3) and osanetant (Table

3) had similar potency at human, dog and gerbil $\mathrm{NK}_{3} \mathrm{R}$ while being approximately 10 fold less potent for the rat $\mathrm{NK}_{3} \mathrm{R}$. Furthermore, the pan-NKR antagonist ZD6021 also displayed 10-fold higher potency at human, dog and gerbil $\mathrm{NK}_{3} \mathrm{R}$ compared to rat $\mathrm{NK}_{3} \mathrm{R}$ (Table 3).

Fig. $3 \mathrm{C}$ illustrates the rhodopsin $\mathrm{NK}_{3} \mathrm{R}$ homology model which emphasizes the role of key residues for talnetant binding. The human $\mathrm{NK}_{3} \mathrm{R}$ positions 265 and 306 differ from all other species studied. The $\operatorname{dog} \mathrm{NK}_{3} \mathrm{R}$ has a Met at position 202 while the other species have an Ile. Nevertheless, based on the pharmacological profile of antagonists at $\mathrm{NK}_{3} \mathrm{R}$ for the various species it appears as if the rat/mouse-specific AA at residues 134, 146 and 317 may play a role in the lower potency of $\mathrm{NK}_{3} \mathrm{R}$ antagonists at rat $\mathrm{NK}_{3} \mathrm{R}$.

\section{Discussion}

It has been known for quite some time that there are major differences in the affinity of many selective $\mathrm{NK}_{1} \mathrm{R}$ antagonists between human and rat/mouse $\mathrm{NK}_{1} \mathrm{R}$. Therefore, since these commonly used experimental animals are not always suitable for evaluation of clinically relevant compounds, other species have been used instead, including gerbils and dogs. Indeed, gerbils have been used for detecting potential behavioural [6] anti-depressive [9], visceral anti-hyper algesic [10] and gut motility [7] effects of $\mathrm{NK}_{1} \mathrm{R}$ antagonists. We recently showed that the gerbil $\mathrm{NK}_{1} \mathrm{R}$ shares key residues (Glu97, Val116, Ile290) with the human $\mathrm{NK}_{1} \mathrm{R}$ homologue and that it has similar affinity for several known $\mathrm{NK}_{1} \mathrm{R}$ antagonists [5] (Fig 1C). Dogs are often used to study the efficacy of anti-emetic compounds like $\mathrm{NK}_{1} \mathrm{R}$ antagonists [15]. The current study extends our previous findings in that the $\operatorname{dog} \mathrm{NK}_{1} \mathrm{R}$ also contains the 
same important residues for antagonist function as human and gerbil $\mathrm{NK}_{1} \mathrm{R}$. This provides confirmation at the molecular level that the dog belongs to the human-like $\mathrm{NK}_{1} \mathrm{R}$ sub-family which has been previously suggested based on experiments in vivo [35]. Interestingly, the compounds ZD6021, CP99,994 and aprepitant were actually slightly more potent (5-10-fold) at $\operatorname{dog} \mathrm{NK}_{1} \mathrm{R}$ compared to gerbil and man. The reason for this is unclear since the receptors display 100\% homology in the TM region. $\mathrm{RP} 67580$, often referred to as a rat-selective $\mathrm{NK}_{1} \mathrm{R}$ antagonist, was equipotent at dog, rat and man. Hence, the rat-selectivity is not supported in the current study and is inline with previous data [5]. Aprepitant is clearly less potent at rat $\mathrm{NK}_{1} \mathrm{R}$ than at $\mathrm{NK}_{1} \mathrm{R}$ from other species. However, based on our data, aprepitant could be useful as a tool compound in rat models since it displays similar potency as $\mathrm{RP} 67580$, an $\mathrm{NK}_{1} \mathrm{R}$ antagonist commonly used in rat models, but appears to have better DMPK properties such as CNS penetration and metabolic half-life [36].

Cloning and sequencing of gerbil and $\operatorname{dog} \mathrm{NK}_{2} \mathrm{R}$ provides data for a more thorough comparison between species. In contrast to $\mathrm{NK}_{1} \mathrm{R}$, rather large discrepancies were found in the TM region in the $\mathrm{NK}_{2} \mathrm{R}$. Residues 202,205 and 267 had a variety of amino acids in this position among species (Fig 2C). Interestingly, all three of these residues have been implicated in the binding of $\mathrm{NK}_{2} \mathrm{R}$ antagonists [37]. Despite the potential importance of these residues for binding and the rather large degree of variation between species, we were unable to identify significant differences of the potency of saredutant and ZD6021 at $\mathrm{NK}_{2} \mathrm{R}$ among the species studied. However, it can not be excluded that the potency of structurally different compounds could have different potency at $\mathrm{NK}_{2} \mathrm{R}$ from gerbil and dog [16].

Consistent with previous findings by [38], both talnetant and osanetant displayed about a 5-10-fold lower potency at the rat $\mathrm{NK}_{3} \mathrm{R}$ compared to the human $\mathrm{NK}_{3} \mathrm{R}$. 
ZD6021 also displayed a relatively weak potency for rat $\mathrm{NK}_{3} \mathrm{R}$ (30-fold weaker than at human $\mathrm{NK}_{3} \mathrm{R}$ ). The current study extends these findings demonstrating that the antagonists tested have similar potency at dog and gerbil $\mathrm{NK}_{3} \mathrm{R}$ as to human $\mathrm{NK}_{3} \mathrm{R}$. Recent data show that talnetant and osanetant interact within overlapping but not identical binding pockets in the human tachykinin $\mathrm{NK}_{3} \mathrm{R}$ trans membrane domains [39]. The human-like pharmacology of gerbil and $\operatorname{dog} \mathrm{NK}_{3} \mathrm{R}$ is consistent with the presence of a methionine located in position 134 , a residue that has previously been shown to be importance for talnetant and osanetant binding to the human $\mathrm{NK}_{3} \mathrm{R}$ (Fig 3C). The Ile317Val AA change may induce less sterical hindrance, and may affect the functional potency of the tested compounds (Fig 3C). The above suggestions support that gerbils and dog represent appropriate species for evaluating the efficacy of tachykinin $\mathrm{NK}_{3} \mathrm{R}$ antagonists intended for clinical use. Indeed, osanetant has demonstrated anxiolytic-like and antidepressant-like effects in gerbils [40]. Single nucleotide polymorphisms in genes encoding receptors can affect many aspects of receptor function and antagonist binding. For instance, four variants of the human $\mathrm{NK}_{2} \mathrm{R}$ are common within the human population [41]. The current study utilized the Thr23_Arg375 variant, however saredutant and ZD6021 display similar potency at all four human variants. If AA-exchanging polymorphisms in NKRs occur within or between strains of the experimental animals compared here is unknown to our knowledge.

Given the above species difference in NKR pharmacology the study of receptormediated toxicology of any NKR modulator, both agonist and antagonists, is not trivial. Ideally, for such studies to be meaningful, selected species for toxicology testing should express the receptor in a similar way and have similar functions as in humans. Concomitantly, selected species should be well characterized with historical 
1

data, in order to differentiate any treatment related lesions from spontaneous

(background) pathology. For these reasons, studies of potential toxicology of $\mathrm{NK}_{2} \mathrm{R}$ antagonists seem to be appropriately conducted in well-known species such as the rat and dog, while dogs appear to suffice for detected potential unwanted effects of $\mathrm{NK}_{1} \mathrm{R}$ and $\mathrm{NK}_{3} \mathrm{R}$ antagonism. 


\section{References}

[1] Quartara L, Altamura M. Tachykinin receptors antagonists: from research to clinic. Curr Drug Targets 2006;7:975-92.

[2] Beresford IJM, Birch PJ, Hagan RM, Ireland SJ. Investigation into species variants in tachykinin NK1 receptors by use of the non-peptide antagonist, CP-96,345. Br J Pharmacol 1991;104:292-93.

[3] Apell KC, Fragale BJ, Loscig J, DSingh S, Tomchuk BE. Antagonists that demonstrate species difference in neurokinin-1 receptor. Mol Pharmacol 1992;41(4): $772-8$.

[4] Saria A. The tachykinin NK1 receptor in the brain: pharmacology and putative functions. Eur J Pharmacol 1999;375:51-60.

[5] Engberg S, Ahlstedt A, Leffler A, Lindström E, Kristensson E, Svensson A, Påhlman I, Johansson A, Drmota T, von Mentzer B. Molecular cloning, mutations and effects of NK1 receptor antagonists reveal the human-like pharmacology of gerbil NK1 receptors. Biochem Pharmacol 2007;73:259-69.

[6] Bristow LJ, Young L. Chromodacryorrhea and repetitive hid paw tapping: models of peripheral and central tachykinin NK1 receptor activation in gerbils. Eur J Pharmacol 1994;253:245-52.

[7] Okano S, Ikeura Y, Inamoti N. Effects of tachykinin NK1 receptor antagonists on the viscerosensory response caused by colorectal distension in rabbits. J Pharmacol Exp Ther 2002;300:925-31.

[8] Greenwood-Van Meerveld B, Gibson MS, Johnson AC, Venkova K, SutkowskiMarkmann D. NK1 receptor-mediated mechanisms regulate colonic hypersensitivity in the guinea pig. Pharmacol Biochem Behav 2003;74:1005-013. 
[9] Varty GB, Cohen-Williams ME, Hunter JC. The antidepressant-like effects of neurokinin NK1 receptor antagonists in a gerbil tail suspension test. Behav Pharmacol 2003;14:87-95.

[10] Kakol-Palm D, Brusberg M, Sand E, Larsson H, Martinez V, Joahnsson A, von Mentzer B,Påhalman I, Lindström E. Role of tachykinin NK1 and NK2 receptors in colonic sensitivity and stress-induced defecation in gerbils. Eu J Pharmacol 2008; 582:123-31.

[11] Fong TM, Yu H, Strader CD,. Molecular basis for species selectivity of the neurokinin-1 receptor antagonist CP-96,345. J Biol Chem 1992;267:25668-71.

[12] Sachais BS, Snider RM, Lowe JA, Krause JE. Molecular basis for species selectivity of the substance P antagonist CP-96,345. J Biol Chem 1993;268:2319-23.

[13] Pradier L, Habert-Ortoli E, Le Guern J, Loquet I, Bock M-D, et al. Molecular determinants of species selectivity of neurokinin type 1 receptor antagonists. Mol Pharmacol 1995;45:314-21.

[14]Sachais BS, Krause JE. Both extracellular and transmembrane residues contribute to the species selectivity of the neurokinin-1 receptor antagonist WIN51708. Mol Pharmacol 1994;46:122-128.

[15] Gardner CJ, Armour DR, Beatttie DT, Gale JD, Hawcock AB, Kilpatrick GJ, Twissell DJ, Ward P. GR205171: a novel antagonist with high affinity for the tachykinin NK1 receptor, and potent broad spectrum anti-emetic activity. Regul Pept 1996;27:45-53.

[16] Meini S, Bellucci F, catalane C, Cucchi P, Pattacchini R, Rotondaro L, Altamura $\mathrm{M}$, Giuliani S, Giolitti A, Maggi C. Mutagenesis at the human tachykinin $\mathrm{NK}_{2}$ receptor to define the binding site of a novel class of antagonists. Eur J Pharmacol 2004;488:61-9. 
[17] Cialdai C, Tramontana M, patacchini R, Lecci A, Catalani C, Catalioto RM, Meini S, valenti C, Altamura M, Giuliani S, Maggi CA. Men 155596, a novel nonpeptide tachykinin NK2 receptor antagonist. Eur J Pharmacol 2006;549:140-8.

[18] Catlioto RM, Criscuoli RM, Cucchi P, Giachetti A, Gianotti D, Giuliani S, Lecci A, Lippi A, Patacchini R, Quartara L, Renzetti AR, Tramontana M, Arcamone F, Maggi CA..MEN 11420 (Nepadutant), a novel glycosylated bicyclic peptide tachykinin NK2 receptor antagonist. Br J Pharmacol 1998;23:81-91.

[19] Advenier C, Rouissi N, Nguyen QT, Emonds-Alt X, Breliere JC, Neliat G, et al. Neurokinin A (NK2) receptor revisited with SR 48968, a potent non-peptide antagonist. Biochem Biophys Res Commun 1992;184:1418-24.

[20] Chung F-Z, Wu L-H, Tian Y, Vartanian MA, Lee H, Bikker J, Humblet C, Pritchard MC, Raphy J, Suman-Chauhan N, Howell DC, Lalwani ND, Oxender DL. Two classes of structurally different antagonists display similar species preference for the human tachykinin neurokinin-3 receptor. Mol Pharm 1995;48:711-16.

[21] Sarau HM, Griswold DE, Potts W, Foley JJ, Schmidt DB, Webb EF, Martin LD, Brawner ME, Elshourbagy NA, Medhurst AD, Giardina GA, Hay DWP. Nonpeptide tachykinin receptor antagonists: I. Pharmacological and pharmacokinetic characterization of SB 223412, a novel, potent and selective neurokinin-3 receptor antagonist. J Pharmacol Exp Ther 1997;281:1303-11.

[22] Wu, Lan-Hsin, Vartainen, Marsha A, Oxender, Dale L, Chung, Fu-Zon. Identification of Methionine134 and Alanine146 in the second transmembrane segment of the human tachykinin NK3 receptor as residues involved in speciesselective binding to SR48968. Biochem Biophys Res Com 1994;198:961-66.

[23] Bernstein PR, Aharony D, Alberts JS, Andisik D, Barthlow HG, Bialecki R, Davenport t, Dedinas RF, Dembofsky BT, Koether G. Dicovery of novel active dual NK1/NK2 antagonists. Bioorg Med Chem Lett 2001;11:2769-73. 
[24] Hale JJ, Mills SG, MacCoss M, Finke PE, Cascieri MA, Sadowski S, Ber E,

Chicchi GG, Kurtz M, Metzger J et al. Structural optimization affording 2-(R)-(1-(R)3,5-Bis(trifluoromethyle)phenyletoxy)-3(S)-(4fluoro)phenyl-4-(3-oxo-1,2,4-triazol-5yl)methylmorpholine, a potent, orally active, long acting morpholine acetal human NK-1 receptor antagonist. J Med Chem 1998;41:4607-14.

[25] Peyronel AT, Moutonnier C, Garret C, Synthesis of RP-67,580, a new potent non- peptide substance P antagonist. Bioorg Med Chem Lett 1992;2:37-40.

[26] McLean S, Ganong A, Seymore PA, Snider RM, Desai MC, Rosen T, Bryce DK, Longo KP, Reynolds LS, Robinson G. Pharmacology of CP-99,994; a nonpetide antagonist of the tachykinin neurokinin-1 receptor. J Pharmacol Exp Ther $1993 ; 267: 472-79$.

[27] Sarau HM, Griswold DE, Potts W, Foley JJ, Schmidt DB, Webb EF, Martin LD, Brawner ME. Nonpeptide tachykini receptor antagonist: I. Pharmacological and Pharmacokinetic characterization of SB 223412, a novel potent and selective neurokinin-3 antagonist. J Pharmacol Exp Ther 1997;281:1303-11.

[28] Giardina GA, Raveglia LF, Grugni M, sarau HM, Farina C, Medhurst AD, Graziani D, Schmidt DB, Rigolio R, Luttman M, cavaguera S, Foley JJ, Vecchietti V, Hay DW. Discovery of a novel class of selective non-peptide antagonist for the human neurokinin-3 receptor. 2. Identification of (S)-N-(1.phenylpropyl-3-hydroxy-2phenylquinoline-4-carboxaamid(SB 223412). J Med Chem 1999;42:1053-65.

[29] Edmonds-Alt X, Bichon D, Dueoux JP, Heaulme M, Miloux B, Ponelet M, Proietto V, van Broeck D, Vilain P, Neliat G, Soubrie P, LeFur G, Breliére JC. SR 142801 the first potent non-peptide antagonist of the tachykinin NK3 receptor. Life Sci 1995;56:PL27-32.

[30] Nguyen-LE X, Nguyen QT, Gobeil F, Pheng LH, Edmonds-Alt X, Breliere JC, Regoli D. Pharmacological characterization of SR 142801: a new non-peptide antagonist of the neurokinin NK-3 receptor. Pharmacology 1996;52:283-91. 
[31] Sundqvist M, Kristensson E, Adolfsson R, Leffler A, Ahlstedt, I, Engberg S,

Drmota T, Sigfridsson K, Jussila R, de Verdier J, Novén A, Johansson A, Påhlman I, von Mentzer B, Lindström E. Senktide-induce gerbil foot tap behaviour is blocked by selective tachykinin NK1 and NK3 receptor antagonists. Eu J Pharmcaol 2007; 577: 78-86.

[32] Larkin,M.A., Blackshields, G., Brown, N.P., Chenna, R., McGettigan, P.A., McWilliam, H., Valentin, F., Wallace, I.M., Wilm, A., Lopez, R., Thompson, J.D., Gibson, T.J., Higgins, D.G. (2007) Clustal W and Clustal X version 2.0.

Bioinformatics 2007;23:2947-48

[33] Teller DC, Okada T, Behnke CA, Palczewski K, Stenkamp R, Stenkamp RE, Advances in determination of a high-resolution three dimensional structure of rhodopsin, a model of G-protein-coupled receptors (GPCRs). Biochemistry 2001;40:7761-72.

[34] Cheng Y, Prusoff WH. Relationship between the inhibitiuon constant (Ki) and the concentration of inhibitor, which cause 50 percent inhibition (IC50) of an enzymatic reaction. Biochem Pharmacol 1973;22:3099-108.

[35] De la Puenta-Redondo V, Tingley FD $3^{\text {rd }}$, Scheider RP, Hickman MA. The neurokinin-1 antagonist activity of marmopitant, an antiemetic drug for dogs, in a gerbil model. J Vet Pharmacol Ther 2007;30:281-287.

[36] Rupniak NMJ, Carlson EJ, Shepheard S, Bentley G, Williams AR, Hill A, Swain C, Mills SG, Di Salvo J, Kilburn R, Cascieri MA, Kurtz MM, Tsao K-L, Gould SL, Chicchi GG. Comparison of the functional blockade of rat substance P (NK1) receptors by GR205171, RP67580, SR140333 and NKP-608. Neuropharmacol 2003; 45:231-241.

[37] Poulsen A, Björholm B, gundetofte K, Pogozheva ID, Liljefors T. Pharmacophore and receptor models for neurokinin receptors. J Computer-Aided Mol Design 2003; 17:765-83. 
[38] Sarau HM, Griswold DE, Bush B, Potts W, sandhu P, Lundberg D, Foley JJ, Schmidt DB, Webb EF, martin LD, Legos JJ, Whitmore RG, barone FC, Medhurst AD, Luttmann MA, Giardina GA, Hay DW. Nonpeptide tachykinin receptor antagonist. II. Pharmacological and pharmacokinetic profile of SB-222200, a central nervous system penetrant, potent and selective NK3 receptor antagonist. J Pharmacol Exp Ther 2000; 295:373-81.

[39] Malherbe P, Bissantz C, Marcuz A, Kratzeisen C, Zenner MT, Wettstein JG, Ratni H, Riemer C, Spooren W. Me-talnetant and osanetant interact within overlapping but not identical binding pockets in the human tachykinin NK3 receptor transmembrane domains. Mol. Pharmacol 2008;73:1736-50.

[40] Salomé N, Stemmelin J, Cohen C, Griebel G. Selective blockade of NK2 or NK3 receptors produces anxiolytic- and antidepressant-like effects in gerbils. Pharmacol Biochem Behav 2006;83:533-539.

[41] Ahlstedt I, Engberg S, Smith J, Perrey C, Moody A, Morten J, LagerströmFermér M, Drmota T, von Mentzer B, Påhlman I, Lindström E. Occurrence and pharmacological characterization of four human tachykinin NK2 receptor variants. Biochem Pharmacol 2008;76:476-481. 
Table 1. Accession numbers for the cloned NKR from human, rat, gerbil and dog and

Acc number

\section{Receptor Species}

$\mathrm{NK}_{1}$ human

$\mathrm{NK}_{2}$ human

$\mathrm{NK}_{3}$ human

$\mathrm{NK}_{1}$ rat

$\mathrm{NK}_{2}$ rat

$\mathrm{NK}_{3}$ rat

$\mathrm{NK}_{1} \quad$ gerbil

$\mathrm{NK}_{2}$ gerbil

$\mathrm{NK}_{3}$ gerbil

$\mathrm{NK}_{1} \quad \operatorname{dog}$

$\mathrm{NK}_{2} \quad \operatorname{dog}$

$\mathrm{NK}_{3} \quad \operatorname{dog}$

$\mathrm{NK}_{1}$ mouse

$\mathrm{NK}_{2}$ mouse

$\mathrm{NK}_{3}$ mouse

$\mathrm{NK}_{1}$

$\mathrm{NK}_{2}$

$\mathrm{NK}_{3}$
NM 001058

AY322545

M89473

J05097

M31838

NM 017053

AJ884917

AJ884918

AM157740

AJ884915

AJ884916

AM423140

NM 009313

NM 009314

NM_021382

guinea pig $\mathrm{P} 30 \overline{5} 47$

guinea pig Q64077

guinea pig P30098 
1

2

3

Table 2. Primers used in the $3^{\prime} R A C E$ and in the $5^{\prime} R A C E$ of $N K_{1} R, N K_{2} R$ and $N K_{3} R$.

$\begin{array}{lllll}\text { receptor } & \text { species } & \text { primer sequence } & \text { reaction } & \text { original sequence } \\ \text { NK1 } & \text { dog } & \text { CCCTCGTAGTCGCCGGCGCTGATAAAG } & \text { 5'RACE } & \text { dog } 575109 \\ \text { NK1 } & \text { dog } & \text { CCCTTTATCAGCGCCGGCGACTACGAG } & \text { 3'RACE } & \text { dog } 575109 \\ \text { NK2 } & \text { dog } & \text { CACTGTAGGCGACGATCATCACCAAGAG } & \text { 5'RACE } & \text { dog } 575024 \\ \text { NK2 } & \text { dog } & \text { TCTCTTGGTGATGATCGTCGCCTACAGTG } & \text { 3'RACE } & \text { dogS75024 } \\ \text { NK3 } & \text { dog } & \text { GGGACCTTCTGGCCATTGCACATAACA } & \text { 5'RACE } & \text { dog } 575029 \\ \text { NK3 } & \text { dog } & \text { CATGCCAGGCCGTACCCTTTGTTATGTGC } & \text { 3'RACE } & \text { dog } 575029 \\ \text { NK2 } & \text { gerbil } & \text { GGAAAGCAAGCCGGAATCCAGAGCG } & \text { 5'RACE } & \text { rat and mouse alignment } \\ \text { NK2 } & \text { gerbil } & \text { GGCTGCCCTACCACCTCTACTTCATCCT } & \text { 3'RACE } & \text { gerbil }\end{array}$


Table 3. Potency of selective NK receptor antagonists and the pan-NKR antagonist ZD6021 on substance $\mathrm{P}\left(\mathrm{NK}_{1} \mathrm{R}\right)$, NKA $\left(\mathrm{NK}_{2} \mathrm{R}\right)$ and Pro7NKB $\left(\mathrm{NK}_{3} \mathrm{R}\right)$ evoked increases in intracellular $\mathrm{Ca}^{2+}$ mobilization. Data are expressed as $\mathrm{pK}_{\mathrm{B}}$ values $\pm \mathrm{SEM}$, $\mathrm{n}=3-5$

$\begin{array}{lllll}\begin{array}{l}\text { Compound } \\ \text { NK } \mathbf{R}\end{array} & \text { Human } & \text { Dog } & \text { Gerbil } & \text { Rat } \\ \text { ZD6021 } & 8.6 \pm 0.4 & 9.5 \pm 0.2 & 9.0 \pm 0.2 & <6 \\ \text { RP67580 } & 7.1 \pm 0.4 & 7.1 \pm 0.6 & 6.5 \pm 0.2 & 7.3 \pm 0.4 \\ \text { CP99,994 } & 8.7 \pm 0.2 & 9.8 \pm 0.3 & 8.9 \pm 0.3 & 5.9 \pm 0.2 \\ \text { Aprepitant } & 8.7 \pm 0.2 & 9.2 \pm 0.1 & 8.8 \pm 0.2 & 7.3 \pm 0.1\end{array}$

$\mathrm{NK}_{2} \mathrm{R}$

ZD6021

$8.3 \pm 0.4$

$8.4 \pm 0.2$

$8.4 \pm 0.3$

$8.1 \pm 0.1$

Saredutant

9.1

$9.4 \pm 0.1$

$9.3 \pm 0.2$

$9.4 \pm 0.1$

$\mathrm{NK}_{\mathbf{3}} \mathrm{R}$

ZD6021

$7.9 \pm 0.3 \quad 7.8 \pm 0.1$

$7.9 \pm 0.1$

$6.7 \pm 0.2$

Talnetant

$8.6 \pm 0.3$

$8.4 \pm 0.2$

$8.4 \pm 0.1$

$7.4 \pm 0.2$

Osanetant

$8.4 \pm 0.5$

$8.2 \pm 0.2$

$8.0 \pm 0.2$

$7.4 \pm 0.3$ 
Legends to Figures

Figure 1. (A): Sequence alignments of $\mathrm{NK}_{1} \mathrm{Rs}$ from gerbil, human, dog, rat, mouse and guinea pig. TM regions are under lined, sequence differences indicated by gray shading and amino acids predicted to be important for antagonist binding are boxed.

(B): Dose-dependent inhibitory effect of the selective $\mathrm{NK}_{1} \mathrm{R}$ antagonist aprepitant on SP-evoked mobilization of intracellular $\mathrm{Ca}^{2+}$ in cells expressing the $\mathrm{NK}_{1} \mathrm{R}$ from various species. Representative curves from each animal from three experiments done, are shown, all performed in the same experiment (see Table 3).(C): Chemical sequences of amino acids interacting in the $\mathrm{NK}_{1} \mathrm{R}$ binding site in the presence of aprepitant. Bold numbers on AA indicate change as compared to the human AA. AA marked in bold show a TM region species difference.

Figure 2. (A): Sequence alignments of $\mathrm{NK}_{2} \mathrm{Rs}$ from gerbil, human, dog, rat, mouse and guinea pig. Tm regions are under lined, sequence differences indicated by gray shading and amino acids predicted to be important for antagonist binding are boxed. (B): Representative curve illustrating the dose-dependent inhibitory effect of the selective $\mathrm{NK}_{2}$ receptor antagonist saredutant on NKA-evoked mobilization of intracellular $\mathrm{Ca}^{2+}$ in cells expressing the $\mathrm{NK}_{2}$ receptor from various species. Representative curves from each animal from three experiments done, are shown, all performed in the same experiment (see Table 3). (C): Chemical sequences of amino acids interacting in the $\mathrm{NK}_{2} \mathrm{R}$ binding site in the presence of saredutant. Bold numbers on AA indicate change as compared to the human AA. AA marked in bold show a $\mathrm{TM}$ region species difference. 
Figure 3. (A): Sequence alignments of $\mathrm{NK}_{3} \mathrm{Rs}$ from gerbil, human, dog, rat, mouse and guinea pig. Tm regions are under lined, sequence differences indicated by gray shading and amino acids predicted to be important for antagonist binding are boxed. (B): Representative curve illustrating the dose-dependent inhibitory effect of the selective $\mathrm{NK}_{3} \mathrm{R}$ antagonist talnetant on NKB-evoked mobilization of intracellular $\mathrm{Ca}^{2+}$ in cells expressing the $\mathrm{NK}_{3} \mathrm{R}$ from various species. Representative curves from each animal from three experiments done, are shown, all performed in the same experiment (See Table 3). (C): Chemical sequences of amino acids interacting in the $\mathrm{NK}_{3} \mathrm{R}$ binding site in the presence of talnetant. Bold numbers on AA indicate change as compared to the human AA. AA marked in bold show a TM region species difference. 
Fig 1A

1 MDNVLPGDSDLEPNISTNSSESNQFVQPAWQ TVLWAAAYTVIVVTSVVGNVVMWIILAHKFWRTVTNYF

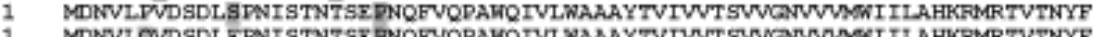

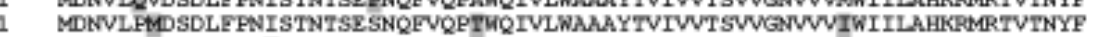
1 MDNVLPVDSDLFPNYSTNTSESNQFVQPTUQTVL WAAAYTVIVVTSVVGNVVIWIILAHKPMRTVTNYF MDNVLPVDSDLFPNISTNTSE PNQFVQPAHOTVLWAAAYTVIVVTSVVGNVVMWIILAHKFMRTVTNYF mi1

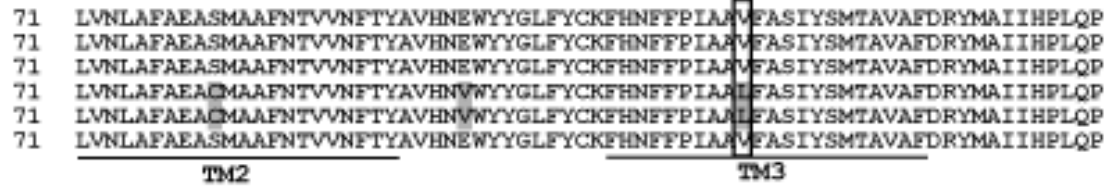

141 RLSATATKVVIFVIMVLALLLAFPQGYYSTTE TMPGRVVOMIEKPEHPNRTYEKAYHICVTVI IFFLPLI

141 RLSATATKVVICVINVLALLLAFPQGYYSTTETMPSRVVCMIEKPEHFNKIYEKVYHICVTVI IFLPLI

141 RLSATATKVVICVIWVLALLLAFPQGYYSTTE TMENRVVCMIEVPEHFNKIYEKVYHICVTVI 1 FLPLL

141 RLSA TATKWVIFVIWVLALLL.AFPOGYYSTTETMPSRVVCMIEGPEHPNRTYEKAYHICVTVI I FFLPLI

141 RLSATATKVVICVIMVLALLLAAEPQGYYSTTE TMPGRVVCMIEKPSHPDKIYEKVYHICVTVII YTLPLL TMA

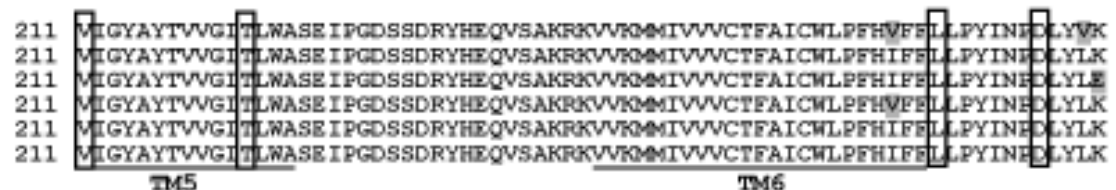
TM6 gerbil NK1r uman NKC1 dog NK1r mouse NKII guinea pig NKL.

gerbil NK1r human NK1r dog NK1r
rat NK1r rat NKIr guinea pig NKlr

gerbil NK1r human NKIr dog NK1r mouse NKC guinea pig MKlr gerbil NKIF human NK1 $\operatorname{dog}$ NKK1r rat NKIr mouse NKIx guinea pig NKIr

281 KFIQQVYLAI ThLAMSS TMNPIIYCCLNDRFRLGFKHAFRCCPFISAGDYEGLEMKSTRYLQTQGSVYK gerbil NK1r

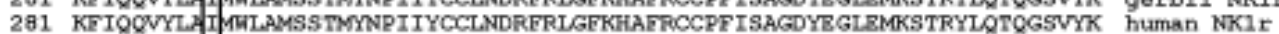

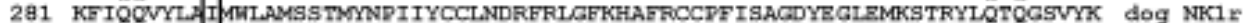

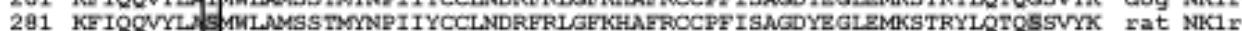

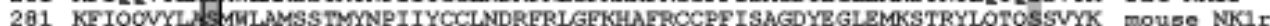
281 KFIQQVYLAI WKLAMSS TMNNIIYCCLNDRFRLGFKHAFRCCPFISAADYEGLMKSTRYFQTQGSVYK guinea pig NKIr TM7

\footnotetext{
351 VSRLETTISTVVEAHEDEXEEGPKATPSSLDLTSNGSSRSWSKTMTESSSEYSMMLX

351 VSRLETTISTVVGAHEEEPEDGPKATPSSLDLTSNCSSRSDSKTMTESFSFSSNVL

351 VSRLETTVSTVVGAHEEELEDGPKTTPSSLDLTSNGSSRSDSKTMTESFSEYSNMLS

351 VSFLETTISTVVGAHEEE VEZGNKATDSSLDLTSNGSSRSNSKTMTE SSSEYSIML. A 351 VSRLETTISTVVGAHEDEDEZGDKATDSSLDLTSNGSSRSNSKTMTESSSEYSMML A 351 VSRLETTISTVVEAHEEDPEEGPAATPSSLDLTSNGSSRSNSKTVTESSSEYSNMLS
}

gerbil NK1r human NK1r dog NKLr rat NK1r mouse NKCI guinea pig NK1r 
Fig 1B

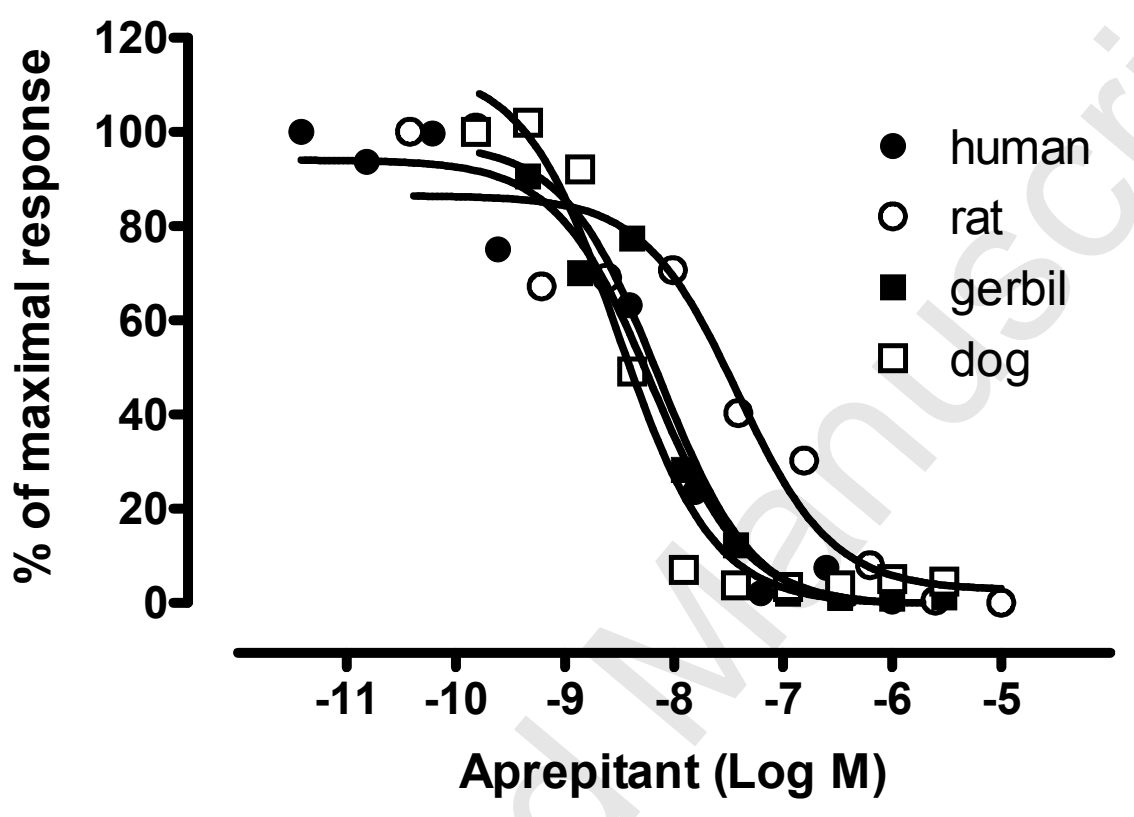


Fig 1C

\section{Species difference in NK1R.}

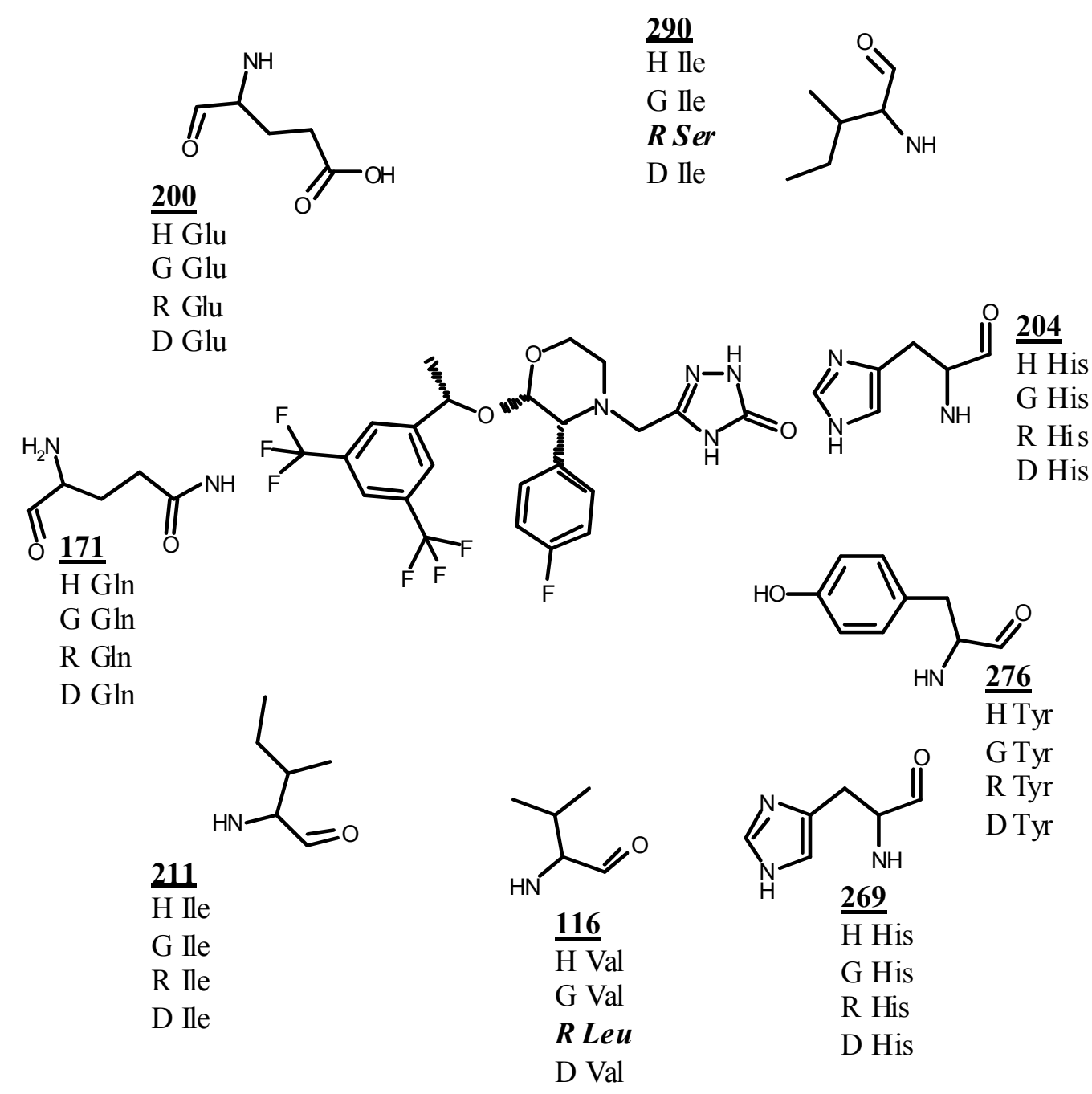

Aprepitant 


\section{Fig 2A}

MGAYAIVTDTNILSGLQGNTTGVTAFSMPAWQLALWTAYLALVLVAVTGNATVIWIILAHEPARTVTNY MGTCDTVTEANI S SGPE SNTTGITAESMPSWQLALWAPAYLALVLVAVTGNATVIWI ILAHIRTMRTVTNY MGAHATVTDANISSSLENNTTGITAFSMPGWOLALWATAYLVLVLVAVTGNA TVIWIILAHOFARTVTNY MCTRATVSDANIL SGLZ SNATGVTAFSMPGWOLALWATAYI.ALVLVAVTGNATVIWI ILAAEFARTVTNY MGAHASVTDTNILSGLE SNATGVTAFSMPGWQLLLWATAYLALVLVAVTGNATVIWI ILAHEFARTVTNY TI

$$
\text { TM1 }
$$

FIINLALADLCMLANATENFYYASHNIWYFGRAFCYFQNLFPITAMFVSIYSMTAIAADRYMATVHFRR

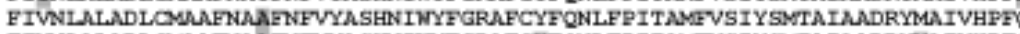
FTWNLALADLCMAAFAAFFVYASHNIWYFGRAFCHFONLFPITAMIV SIYSMTAIAADRYVAIVHPFO FI INLALADLCMAAFNA TENF TYASENIWYTGRAFCYF ONLFPITAMEVSTYSMTAIAADR YMATVHPFO

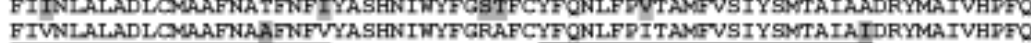
TM2 TM3

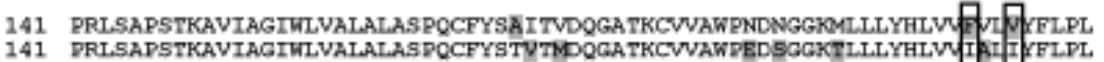

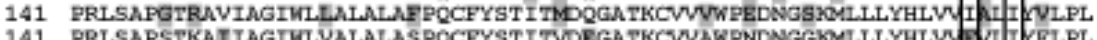

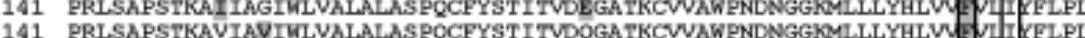

141 PRLSAPSTKAVIGGTKLVALALLAFPOCFYSTITEDEGATKCVVAWPEDSRDKSLLLYHLVV IT IXLLPL TM4 TMM

211 VMMPAXYSVIGLTLMKPAVPRHOAHGANLRHLOAKKKEVKAMVIVUITFAICNL 211 AVMFVA YSVI GLTL WRRAVPGHOAHGANLRFL OAKKKFVKTMVIVULTFATCNLP 211 LVMLIAYSVIGLTL NRFEVTRHOVHCASLRHLRAKCKKFVKTMVIVVVTFAICWL Y

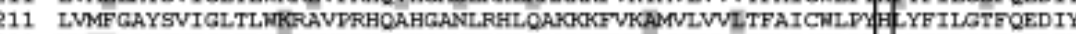

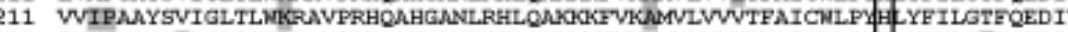

211 TVMFVAYSIIGLTLNRPAVPRHQAHGANLRHLQAKKKFVKTMVLVVTFAICWLP YI Y YFILGSEQEDIY TTM6

281 YHKF IQQVYLALIFL.AMSSTMMPI IYCCLNHRFRSGFRLAFRCCPVVTPTEEDRLELTRTPSVSRRVNR 281 CHKFIQCVYLALFWLAMSSTMNPI IYCCUNHRFRSGFRLAFRCCPWVTPTKEDKLELTPTTSLSTRVNR 281 YHKF I COVYLALFWLAMSSTMNPI IYCCLNHRTRSGFRLAFRCCPWVTPTEEDKIELTHTPSLSARTNR 281 YHKF I Q OVYLALFWLAMSSTMYNPI IYCCLWHRFRSGFRLAFRCCPWVTPTEEDRLELTHTPSLSRRVNR 281 YRKF I $Q$ CVYLALFWL.AMSSTMMNDI IYCCLNHRFRSGFRLAFRCCPWGTDTYEDFLELTHTDSISRRVNR 281 CHKF IQQVYLALFWLAMSSTMNPIIYCCLNRRFRSGFRLAFRCCPWVTPTEEDKLELTHTPSESLRVNR TM7 gerbil NK2r human NK2r dog NK2r ate2 2 nouse NR22 guinea pig NK2r gerbil NK2 $x$ human NK2 $x$ dog NK2r at NK2r guinea pig NK2r

gerbi1 NK2: human NK22r dog NK2r

rat NK2r mouse NK2r guinea pig NK2r

gerbil NK2r human NK2r dog $\mathrm{NK}_{2} \mathrm{r}$ rat NKC2r mouse NK2 $r$ guinea pig NK2r human NK2r dog NK2r rat NK2r guinea pig NK2r gerbil NKC2r human NK22 dog NK2 $x$ rat NK2r mouse NK2r guinea pig NK2 
Fig 2B

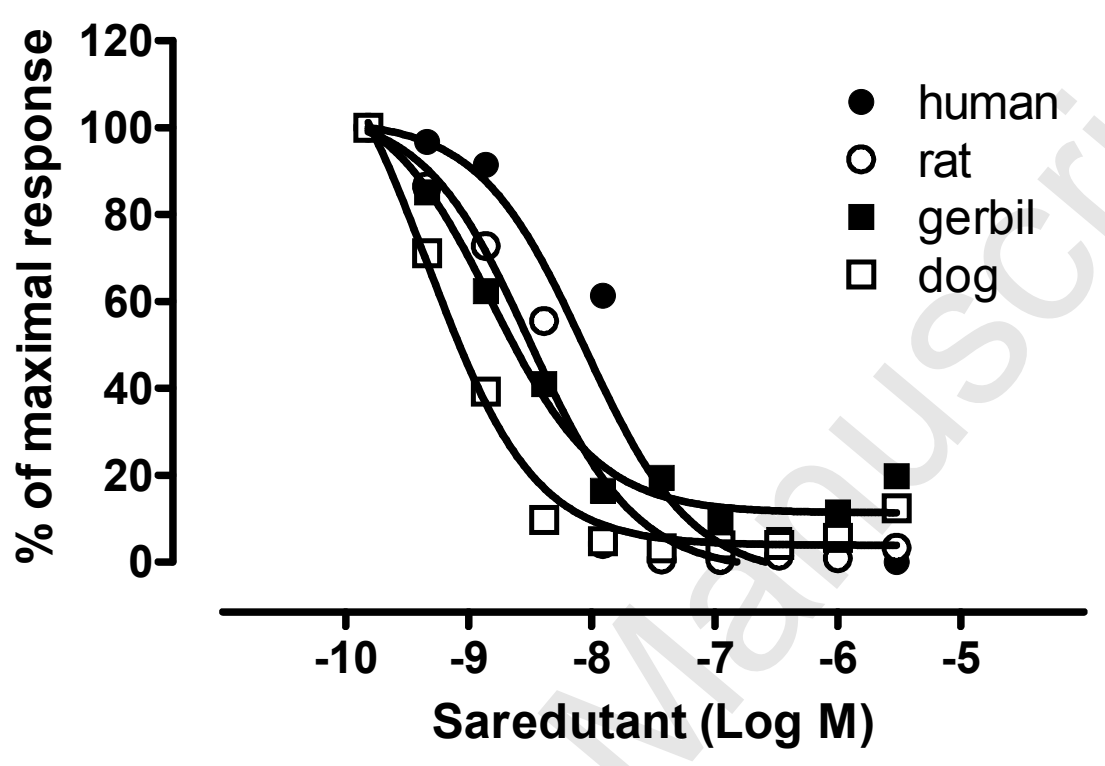


Fig 2C

\section{Species difference in NK2R}

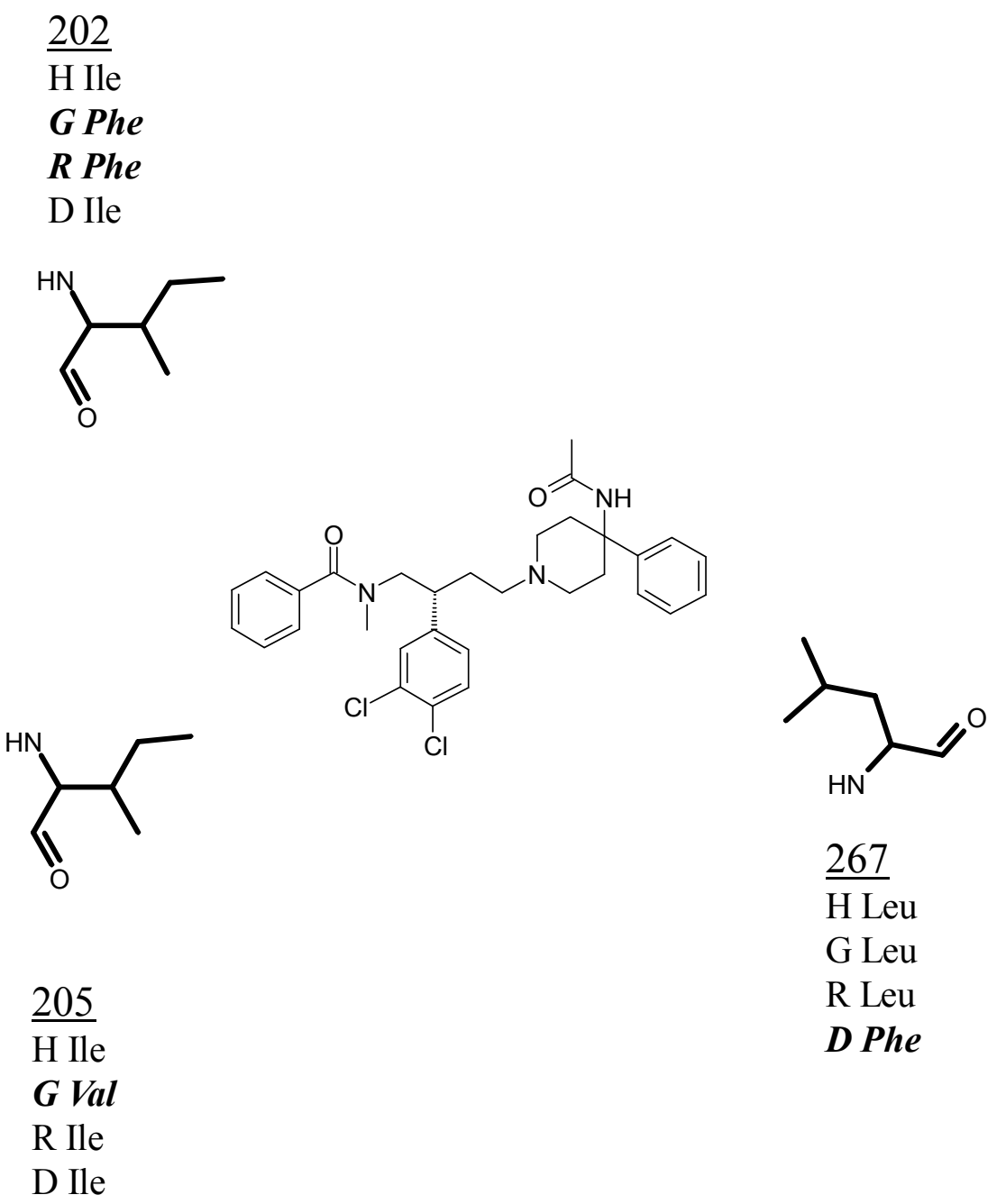

SR48968 

MATLDAAET--KIDGCOGVGADAVNLTASIAAGAATGAVETGKLQLIDQAGNLSSSDSALGLDVASDADS

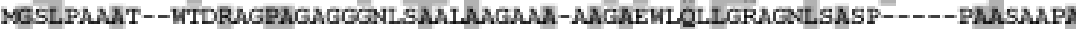
MASVPRGEN--KTDGTVEVGPHTGNLSSALGV-----TEVLALQ--AGNFSSALG---LPATTQAPS MASVPTGEN--KTDGTAGVGSHTGNLSARLGI-------TEKLALQ--AGNFSSALG---LPVTSQAPS

5B QARANLTNQFVQPSURIALWSLAYGLVVAVAVGNLIVIUI ILAHKRMRTVTNYTLVNLAFSDAS 69 QPWANLTNOFVOPSKRIALWSLAYGVVVAVAVLGNLTVIKI ILAHKRMRTVTNYFLVNLAE SDAS A AAFN

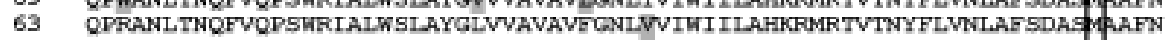

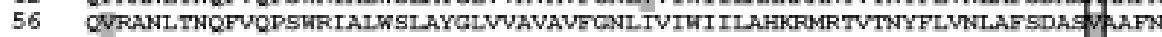
56 QVRANL TNQFVQPSWRIALWSLAYGLVVAVAVEGNLIVIUI ILAHIKRMRTVTNYFLVNLAESDAS WAFN 45 -PRPGPAHPFLOPPURVALWSLAYGAVVAVAVLGNLVIVIVLAHKRMRTVTNSFLVNLAFADA2 IM1 712

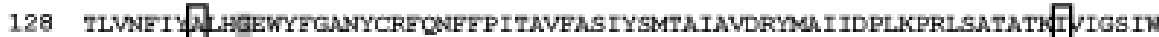

139 TLVNFI 2 HSEWYFEANYCRFCNFEPITAVFAS TYSMPAIAVDRYMAITDPLKPRLSATATKIVIGSIV 133 TLVNEI 2 LHSEWYEGANYCRECAFEPITAVEAS IYSMTAIAVDRMAIIDPLKPRLSATATK VIGSIM 126 TLDNEI G GHSEWYGGANYCREGNFEPITAVFAS TYSMTAIAVDRYMA I IDPLKPRLSATATK FIGS IV

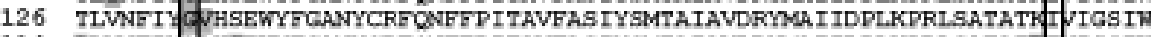

114 ALVNEI \& LHGEWYFGANYCREGNEEPITAVEAS IYSMTAIAVDRYMIIDPLKPRLSATATREVIGS IV TM3 3

198 ILAFLI.AEDQCLYSKIKYMDGRTLCYVQWDEGNKOHFTYHI TVI ILVYCEDLL. IMAOTYTIVGITLWGGE

209 II.AFLLAEDOCLYSKTKMMDGRTLCEVOWDEGDKOHFTYHI IVIILVYCEDLL. IM IITYTIVGITLWGGE

203 ILAFLIAEPQCLYSKIKMMGRTLCYVQWPEGPKOHFTYHI IVIILVYCFPLLIMQVIYTIVGITLWGGE

196 ILAFLLAFPQCLYSKIKVMPGRTLCYVQVPEGPKQHFTYHI IVIILVYCEPLLIM V IYT IVGITLWGGE

196 ILAFLLAFPQCLYSKIKVMPGRTLCYVQWPEGPKOHFTYHI TVI ILVYCEPLLTM Y IYTIVGITLWGGE

184 ILAFLLAEPQCLYSKIKVMPGRTLCYVQMPEGSROHFTYHMIVIVLVYCEPLLIMA ITYT TVGITLWGGE TM4 $\mathrm{ZM5}$

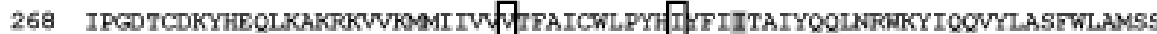

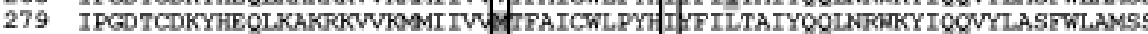

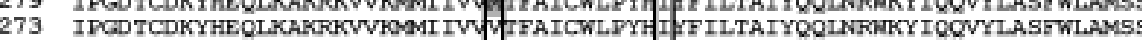

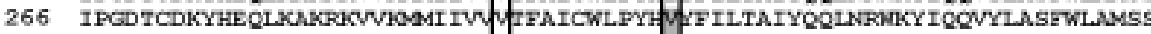

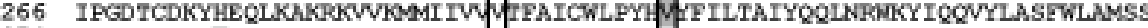

254 IPGD TCDKYQEQLKAKRKVVNMIIV IPAICWLPYH IF ILTAIYQQLNRNKYIQCVYLASEWLAMSS TM6

TMMNPI IYOCLMKRERAGEKRAFRWCPEIQVSSYDELELKT TRFHPTRQSSLYTVSRMESVTVLPDENDG TMYNPI IYCCLNIKRERAGEKRAFRNCPFIKVSSYDELELKT TRPHPNRQSSMYTVTRMESMTVVIDENDA TMYNPI TYCCLNKRRRAGEKRAFTWCPFTELSNYDELZLKTIRFHPTRBSSLYTVTRMESMTVVREPSN TMYNDI IYCCL.NKRERAAGEKRAFFWCDEIQVSSYDELIILKT TRFHDTRQSSLYTVSRME SVTVLFDPNDC

336 TMYNDI TYCCL.NKRRFAGEKRAFFWCDF IOVSSYDELILLKTTRFHDTRQSSLYTVSRMESVTVLYDPSEO

324 TMMNPI IYOCL.NKRERAGEKRAFRNCPE IHVSSYDEL.ZLKATRLHRNAQSSL YTVTRME SMSVVIDSNDG TM7

408 DDAKSSRKKKAVDRDDSTNCCARWDSKSASTTSSEISSPYTSVDEYS

419 DTTRS SRIEKRATPRDPSENGCSRPNSKSASATSSEISSPYTSVDEYS

413 DNTKSSRKIKRV TRDPSFSGCSRRNSKSASTTSSFISSPYTSVDEYS

406 DPTKSSRKKRAVPRDPSANGCSHRGSKSASTTSSFISSPYTSVDEYS

406 DPAKSSRKKRAVPRDPSANGCSHREFKSASTTSSFTSSPYTSVDEYS

394 DSARSSHOKRGTTRDVGSNVCSRFNSKSTSTTASFVSSSHMSVEIGS

gerbil NK3r human NK3r dog $\mathrm{NK} 3 \mathrm{r}$ rat NK3r mouse NK3r guinea pig NK3r

gerbil NK3r human NK3r dog NKSTr rat NKG $x$ mouse NK3r guinea pig NK3r

gerbil NK3r human NK3r dog NKBr rat NK3r guinea pig $\mathrm{NK}^{3} \mathrm{r}$

gerbil NKG human NK3r dog $\mathrm{NK}^{2} \mathrm{r}$ rat $\mathrm{NK3r}$ mouse NKC3x guinea pig NKC

gerbil NK3r human NK3r dog NKS $x$ rat NK3r mouse NK3r guinea pig NK3r

gerbil NK3r human NK3r dog NKBr rat $\mathrm{NKB}^{2}$ mouse NK3r guinea pig NK3r

gerbil NKGr human NK3 dog $\mathrm{NK} 3 \mathrm{r}$ rat NK3r mouse NKK3x guinea pig $\mathrm{NaC}_{3} \mathrm{x}$ 
Fig 3B

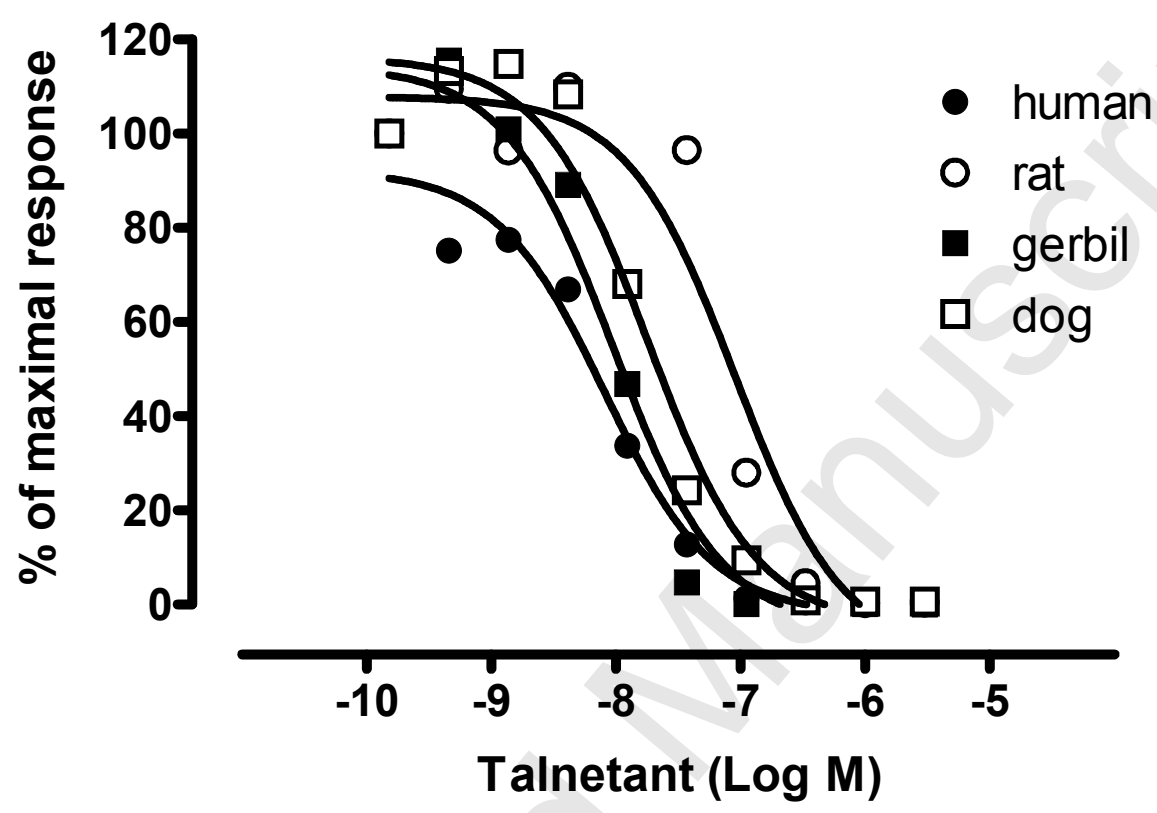


Fig 3C

\section{$\underline{\text { Species difference in NK3R }}$}

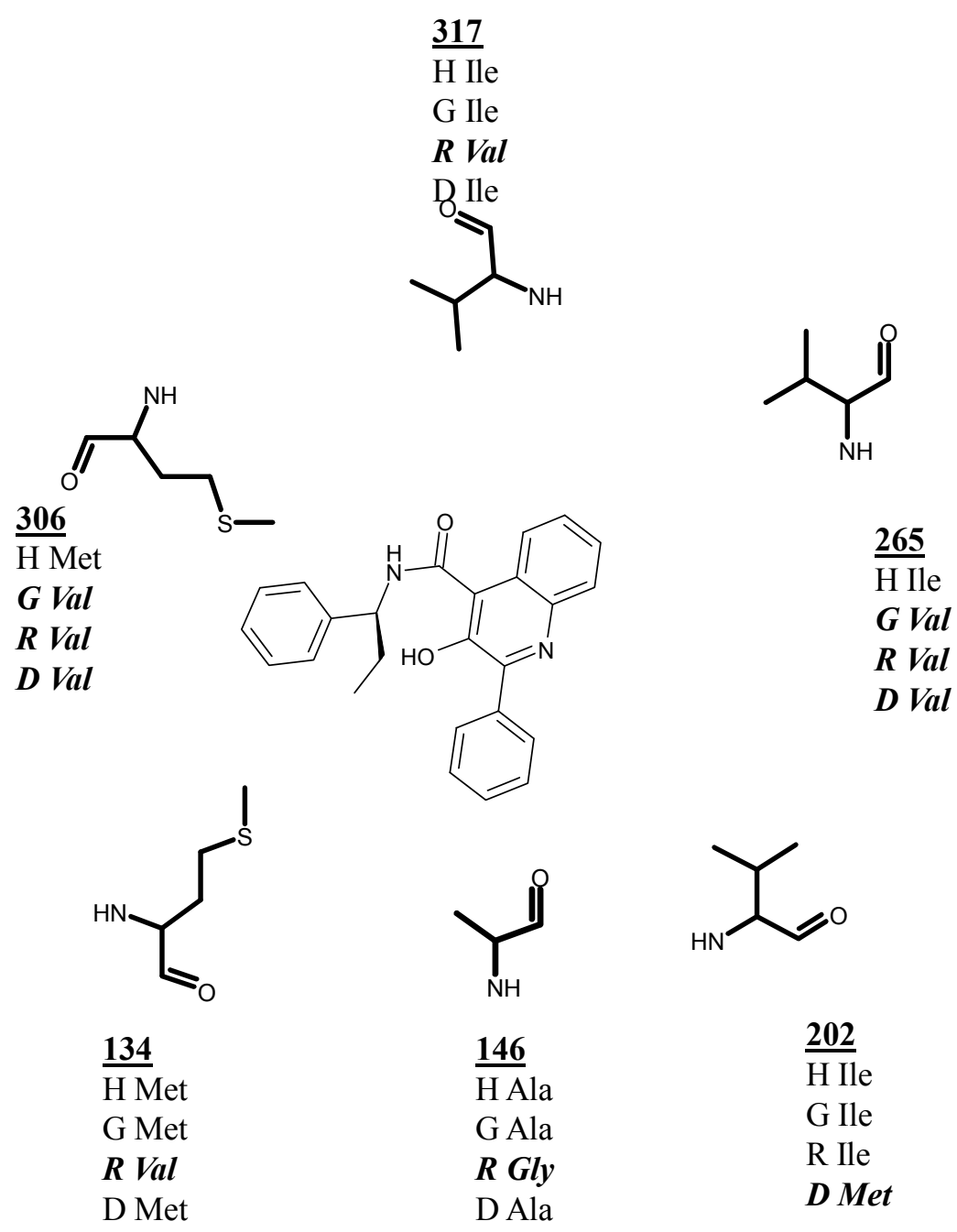

\section{Talnetant}


Experiments with Neurokinin receptors (NKR) demonstrate that not only human, but also dog and gerbil NKR displays similar antagonist pharmacology while rat diverges significantly with respect to $\mathrm{NK}_{1} \mathrm{R}$ and $\mathrm{NK}_{3} \mathrm{R}$.

Potencies of selective NKR antagonists and of the pan-NKR antagonist ZD6021.

Compound

$\mathrm{NK}_{\mathbf{1}} \mathrm{R}$

ZD6021

RP67580

CP99,994

Aprepitant

$\mathrm{NK}_{2} \mathrm{R}$

ZD6021

Saredutant

$\mathrm{NK}_{\mathbf{3}} \mathrm{R}$

ZD6021

Talnetant

Osanetant

\section{Human}

$8.6 \pm 0.4$

$7.1 \pm 0.4$

$8.7 \pm 0.2$

$8.7 \pm 0.2$

$8.3 \pm 0.4$

9.1

$7.9 \pm 0.3$

$8.6 \pm 0.3$

$8.4 \pm 0.5$
Dog

$9.5 \pm 0.2$

$7.1 \pm 0.6$

$9.8 \pm 0.3$

$9.2 \pm 0.1$

$8.4 \pm 0.2$

$9.4 \pm 0.1$

$7.8 \pm 0.1$

$8.4 \pm 0.2$

$8.2 \pm 0.2$
Gerbil

$9.0 \pm 0.2$

$6.5 \pm 0.2$

$8.9 \pm 0.3$

$8.8 \pm 0.2$

$8.4 \pm 0.3$

$9.3 \pm 0.2$

$7.9 \pm 0.1$

$8.4 \pm 0.1$

$8.0 \pm 0.2$

\section{Rat}

$<6$

$7.3 \pm 0.4$

$5.9 \pm 0.2$

$7.3 \pm 0.1$

g

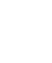

\author{
(2)
}

